\title{
Crassostrea patagonica (d'Orbigny, 1842) shell concentrations from the late Miocene of Río Negro province, NE Patagonia, Argentina
}

\author{
Rosa DOMÈNECH ${ }^{*}$, Ester A. FARINATI² \& Jordi MARTINELL ${ }^{1}$
}

${ }^{1}$ IRBio \& Departament d'Estratigrafia, Paleontologia i Geociències Marines, Facultat de Geologia, Universitat de Barcelona (UB), Martí i Franquès s/n, 08028 Barcelona, Spain; rosa.domenech@ub.edu; jmartinell@ub.edu

${ }^{2}$ Departamento de Geología, Universidad Nacional del Sur, San Juan 670, 8000 Bahía Blanca, Argentina; farinati@uns.edu.ar

* Corresponding author

Domènech, R., Farinati, E.A. \& Martinell, J. 2014. Crassostrea patagonica (d'Orbigny, 1842) shell concentrations from the late Miocene of Río Negro province, NE Patagonia, Argentina. [Concentraciones de conchas de Crassostrea patagonica (d'Orbigny, 1842) en el Mioceno superior de la provincia de Río Negro, NE Patagonia, Argentina]. Spanish Journal of Palaeontology, 29 (2), 165-182.

\begin{abstract}
The Río Negro Formation (late Miocene-early Pliocene) mainly consists of continental deposits, but it contains a middle member of marine origin. It represents a transgressiveregressive sequence that can be seen at several outcrops along the N Patagonian coast. The taphonomical approach to the El Espigón marine deposits permits the identification of four main layers containing different kinds of skeletal accumulation, which mainly consist of oyster shells [Crassostrea patagonica (d'Orbigny, 1842)]. These concentrations display three different morphologies (pouches, pavements and bouquets) with a different taphonomic signature. These deposits were formed in shallow marine environments influenced by wave activity that produced valve concentrations of different entities. They contain several shell beds that represent event, composite, hiatal to lag skeletal concentrations. Traces of bioturbation in the sediment (Thalassinoides, Teichichnus) and bioerosion on the shells (Entobia, Gastrochaenolites, Caulostrepsis), and encrusters (cirripeds, bryozoans), are also
\end{abstract}

\section{RESUMEN}

La Formación Río Negro (Mioceno superior-Plioceno inferior) consiste principalmente en depósitos continentales, pero contiene un Miembro Medio de origen marino. Este miembro representa una secuencia transgresiva-regresiva observable en diversos afloramientos a lo largo de la costa $\mathrm{N}$ patagónica. El análisis tafonómico a los depósitos marinos de El Espigón permite la identificación de cuatro capas principales que contienen distintos tipos de acumulaciones esqueléticas, principalmente formadas por conchas de ostras [Crassostrea patagonica (d'Orbigny, 1842)]. Estas acumulaciones muestran tres morfologías distintas (bolsadas, pavimentos y ramilletes) con señales tafonómicas diferenciadas. Los depósitos se formaron en ambientes marinos someros afectados por oleaje, dando lugar a la formación de acumulaciones de conchas con entidades distintas. Los depósitos contienen capas de conchas que representan concentraciones de evento, compuestas, y de hiato a residuales. Son también abundantes en el afloramiento las trazas de bioturbación (Thalassinoides, Teichichnus), 
abundant in the outcrop and constitute common components of these Miocene materials. Layers 1 and 2 of the sequence were deposited in shoreface/foreshore environments at the beginning of a highstand systems tract, while layers 3 and 4 were deposited at the end, or at the beginning of a forced regression, in foreshore environments. A final erosional episode cut the top of layer 4 , which truncated the abundant bioturbation developed there.

Keywords: Taphonomy, shellbeds, ichnology, bioerosion, bioturbation, Neogene.

\section{INTRODUCTION}

The interest in the study of the taphonomic attributes of shell concentrations in palaeoenvironmental analyses and in sequence stratigraphy is widely recognized and numerous articles have been published on this issue, both theoretical and applied, over a long period of time (e.g., Kidwell, 1986, 1991 a, b, c; Brandt, 1989; Fürsich \& Oschmann, 1993; Brett, 1995; Abbott, 1997, 2000; Kondo et al., 1998; Fürsich \& Pandey, 1999, 2003; Holland, 2001; Botquelen et al., 2004; Cantalamessaa et al., 2005; Parras \& Casadío, 2005, 2006; Pufahl \& James, 2006; Damborenea \& Lanés, 2007; Kietzmann \& Palma, 2009; Ragaini \& Di Celma, 2009; Yamashita et al., 2011; Sharafi et al., 2012). Among shells, oysters represent an especially interesting tool for taphonomic inferences and palaeoenvironmental reconstructions because of their abundance and high preservation potential, and also their role as bioherm builders (Parras \& Casadío, 2005; Pufahl \& James, 2006).

The excellent fossil record of the marine Phanerozoic deposits in Argentina has allowed for many palaeontological studies with a clear taphonomic component and palaeoenvironmental analysis. These studies demonstrate the utility of shell concentrations to obtain valuable data for both sequence stratigraphy and basin analysis. In this regard, it is worth mentioning papers such as del Río et al. (2001) on the late Miocene marine shell beds of the Puerto Madryn Formation in the Valdés Península and Puerto Madryn area (Patagonia); Parras \& Casadío (2005) on Oligocene oyster-dominated concentrations from the San Julián Formation (Patagonia); or Damborenea \& Lanés (2007) on Early Jurassic shell beds from marginal marine environments of Mendoza. All these studies are based on large three-dimensional skeletal concentrations, mainly composed by oysters and other bivalves.

However, it is not only these spectacular layers that provide information. Minor three-dimensional as well as de bioerosión en las conchas (Entobia, Gastrochaenolites, Caulostrepsis) y los incrustantes (cirrípedos, briozoos), y representan componentes comunes de estos materiales miocenos. Las capas 1 y 2 de la secuencia se depositaron en ambientes de anteplaya/playa baja al principio del cortejo de nivel alto (highstand systems tract), mientras que las capas 3 y 4 lo hicieron hacia el final, o al inicio de una regresión forzada, en ambientes de playa baja. Un episodio erosivo final cortó la parte superior de la capa 4, truncando la abundante bioturbación allí desarrollada.

Palabras clave: Tafonomía, capas de conchas, icnología, bioerosión, bioturbación, Neógeno. bi-dimensional shell accumulations also have potential, which has not been fully exploited. In this context, Videt (2007) draws attention to all these types of oyster concentrations and demonstrates its usefulness to highlight discontinuities within sedimentary successions.

Thus, the cliffs of the Río Negro Fm exposed along the Atlantic shore of Northeastern Patagonia are characterized by several thin shell concentrations dominated by Crassostrea patagonica (d'Orbigny, 1842) offering a good opportunity for taphonomic and palaeoenvironmental studies. Based on previous work (Zavala \& Freije, 2000; Farinati \& Zavala, 2005; Domènech \& Farinati, 2007), the present study focuses on the taphonomic analysis of these oyster concentrations in one of the accessible outcrops of the Río Negro Fm, and on their interpretation in the context of the sequence stratigraphic framework established in the area (Zavala \& Freije, 2000; Carmona et al., 2013).

\section{GEOGRAPHIC AND GEOLOGIC SETTING}

The Argentinian marine Miocene is characterized by extensive exposures on the Atlantic coast, which bear an abundant record of fossil invertebrates (molluscs, corals, cirripeds, bryozoans, echinids, etc.), and traces of organic activity (both bioturbation and bioerosion). Among those exposures, the Puerto Madryn Fm strata that outcrop in Valdés Península and the area surrounding the city of Puerto Madryn, have been especially analyzed (del Río, 1988, 1992, 1994; del Río \& Martinez, 1998; del Río et al., 2001; Mauna et al., 2005). This formation is Late Miocene in age (Scasso et al., 2001) and it covers a complete transgressive-regressive cycle.

The working area chosen for the present study is located in the NE of Argentinian Patagonia, in the province of Río Negro. The particular area studied is the North shore 
of the San Matías Gulf, south of Viedma city (Fig. 1). The landscape is a barren steppe which is marked by major marine cliffs where it meets the Atlantic Ocean. These cliffs contain excellent marine and continental outcrops belonging to the late Miocene-early Pliocene interval, assigned to the Río Negro Fm (Andreis, 1965), and are coeval with the Puerto Madryn Fm strata (Zavala $\&$ Freije, 2000). The marine sediments are characterized by an abundant, although little diversified, invertebrate fossil fauna that allows for interesting taphonomic and palaeoenvironmental inferences.

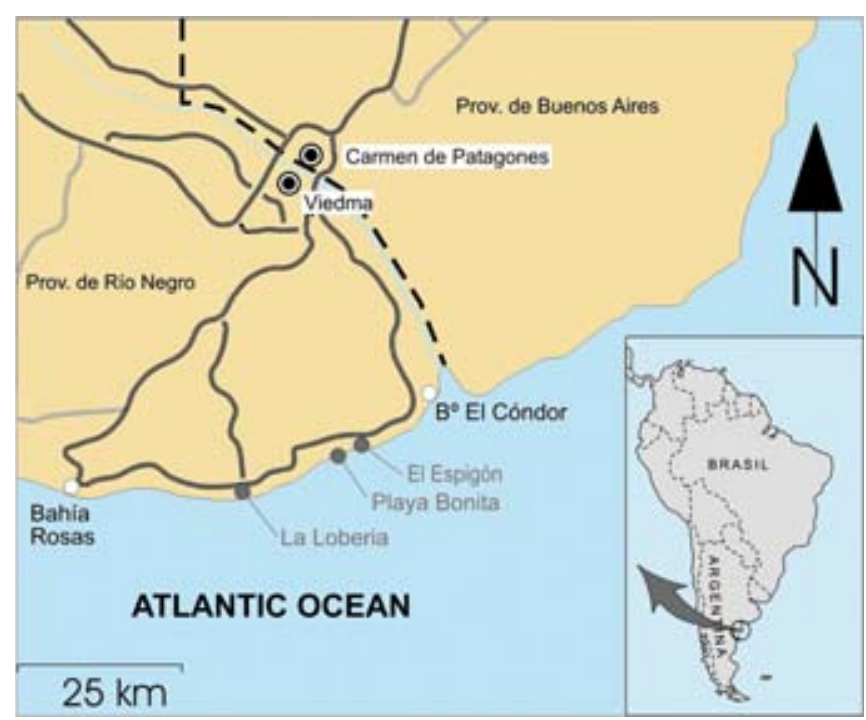

Figure 1. Geographical situation of El Espigón outcrop, Río Negro Province, Patagonia, Argentina.

\section{STRATIGRAPHICAL SETTING OF THE RIO NEGRO FORMATION}

\subsection{General features of the Formation}

The study of the Río Negro Fm cliffs reaches back more than 170 years to when d'Orbigny (1842) carried out the first observations in the Carmen de Patagones area (Buenos Aires province). Thereafter, he was followed by other authors like Roth (1898), Wichmann (1918), Frenguelli (1950), Feruglio (1950), Andreis (1965), De Ferraris (1966), Farinati et al. (1981), Angulo \& Casamiquela (1982), Zavala \& Freije (2000), Farinati \& Zavala (2002, 2005), Domènech \& Farinati (2007), Farinati et al. (2010), Carmona et al. (2012, 2013), among others.

The coastal outcrops of the Río Negro Fm are composed mostly of blue-gray mudstones and sandstones that appear as almost horizontal strata between Bahía Rosas and
Balneario El Cóndor (Fig. 1), with a great lateral continuity for over $100 \mathrm{~km}$ and a thickness exceeding $50 \mathrm{~m}$.

This formation was initially interpreted as a unit of fluvial origin (Andreis, 1965). However, it is currently interpreted as a mostly aeolian unit (Zavala et al., 2000; Zavala \& Freije, 2000) that contains a marine intercalation in its middle part and along some $60 \mathrm{~km}$ (Farinati et al., 1981; Angulo \& Casamiquela, 1982; Carmona et al., 2013). Thus, Zavala et al. (2000) and Zavala \& Freije (2000) described a lower and an upper aeolian member, with an unconformably lying inserted middle marine member. The lower member consists of medium to coarse-grained sandstones and mudstones deposited in an aeolian environment. The upper member is composed of sandstones also deposited in an aeolian setting, at the base, followed by palaeosols and tuff levels at the top. The middle member is described in detail in the next section.

All members were described as bounded by sharp erosional discontinuities (Zavala et al., 2000). Nevertheless, Carmona et al. (2012) describe gradational transitions between them in some protected areas where microbially induced sedimentary structures appear. The development of those microbial mats in tidal flat settings contributed to the preservation of vertebrate trace fossils, including a particular abundance of mammal and bird footprints in the levels immediately below and above the marine member (Casmiquela, 1974; Aramayo, 1987, 2007; Aramayo et al., 2004; Melchor et al., 2012; Carmona et al., 2013).

\subsection{The middle marine member of the Formation}

The marine unit of the Río Negro Fm cliffs (middle member) is composed of gray mudstones and fine-grained bioclastic sandstones deposited in a shallow offshore to beach marine environment, affected by wave action in a partially confined setting. This marine member presents a maximum thickness of up to $10 \mathrm{~m}$ and a large-scale lenticular geometry. Following Farinati \& Zavala (2005), offshore facies consist of massive bioturbated mudstones (Cruziana Ichnofacies, represented by Chondrites) where abundant oyster concentrations have been recognized. They grade, towards marginal sectors, to lower shoreface facies composed of mudstones and fine-grained, bioturbated sandstones (Cruziana Ichnofacies, represented by Thalassinoides, Planolites and Chondrites). Finally, foreshore and upper shoreface facies of the marginal sectors are composed of fine sandstones rich in invertebrate skeletons (Oculina, Balanus, Ostrea, Pododesmus, Chlamys), bioerosion on the shells (Entobia, Caulostrepsis, Gastrochaenolites) and bioturbation (Skolithos Ichnofacies, represented by Ophiomorpha and Skolithos). Carmona et al. (2013) revisited this formation from the ichnological point of view, describing a Cruziana Ichnofacies at the base 
of the marine member (with Ophiomorpha, Teichichnus, Siphonichnus, Asterosoma), a Glossifungites Ichnofacies in the middle section (with Ophiomorpha, Asterosoma, Teichichnus, Siphonichnus), a Skolithos Ichnofacies in the upper part (with Ophiomorpha and Maiakarichnus), and a Cruziana (or Psilonichnus)-Skolithos Ichnofacies at the top of the member (with Ophiomorpha or Arenicolites).

According to the sequence stratigraphic analysis, these deposits are part of a depositional sequence recording a complete marine transgressive-regressive cycle whose main control would have been glacioeustatism (Zavala \& Freije, 2000, 2001). Zavala \& Freije (2000) analyzed 5 sections containing the middle member (Escalera, La Lobería, Playa Bonita, El Espigón and El Faro) along the entire exposure area of the formation. They identified a basal transgressive system tract (TST) followed by a highstand system tract (HST) and some higher levels corresponding to a forced regression (FR) due to a relatively rapid sea-level decline (Fig. 2). Nevertheless, Carmona et al. $(2012,2013)$ interpret the top of the member as tidal flat deposits, with vertebrate traces, suggesting a not so sharp but a progressive transition to the aeolian deposits of the upper member.
Domènech \& Farinati (2007) recognised two distinct major oyster shell concentrations in this marine middle member: level 1, located in the upper section of the transgressive tract, composed of moderately bioturbated, massive mudstones in which monospecific pockets of C. patagonica (cited there as Ostrea patagonica) were recognized; and level 2, located in the HST, where $C$. patagonica shells were also dominant, in this case arranged in pavements. Previously, Farinati \& Zavala (2002) studied the bioerosion present in oysters from the pavements of this marine member, based on material collected in La Lobería, Playa Bonita and El Espigón outcrops.

According to its position in the sequence and to $\mathrm{K}-\mathrm{Ar}$ dating of equivalent marine deposits in the area (9.41 My, Zinsmeister et al., 1981) and dating of ${ }^{87} \mathrm{Sr} /{ }^{86} \mathrm{Sr}$ on bivalves of the Puerto Madryn Fm ( $10 \pm 0.3$ My, Scasso et al., 2001), the marine member of Río Negro Fm was assigned to the late Miocene (Tortonian) (Zavala \& Freije, 2000). Moreover, the vertebrate findings at high levels in the upper member (Aramayo, 1987) indicated a Montehermosean Mammal Age (early Pliocene), which would support the dating of the middle member.

$\begin{array}{cc}\text { La } & \text { Playa } \\ \text { Lobería } & \text { Bonita }\end{array}$

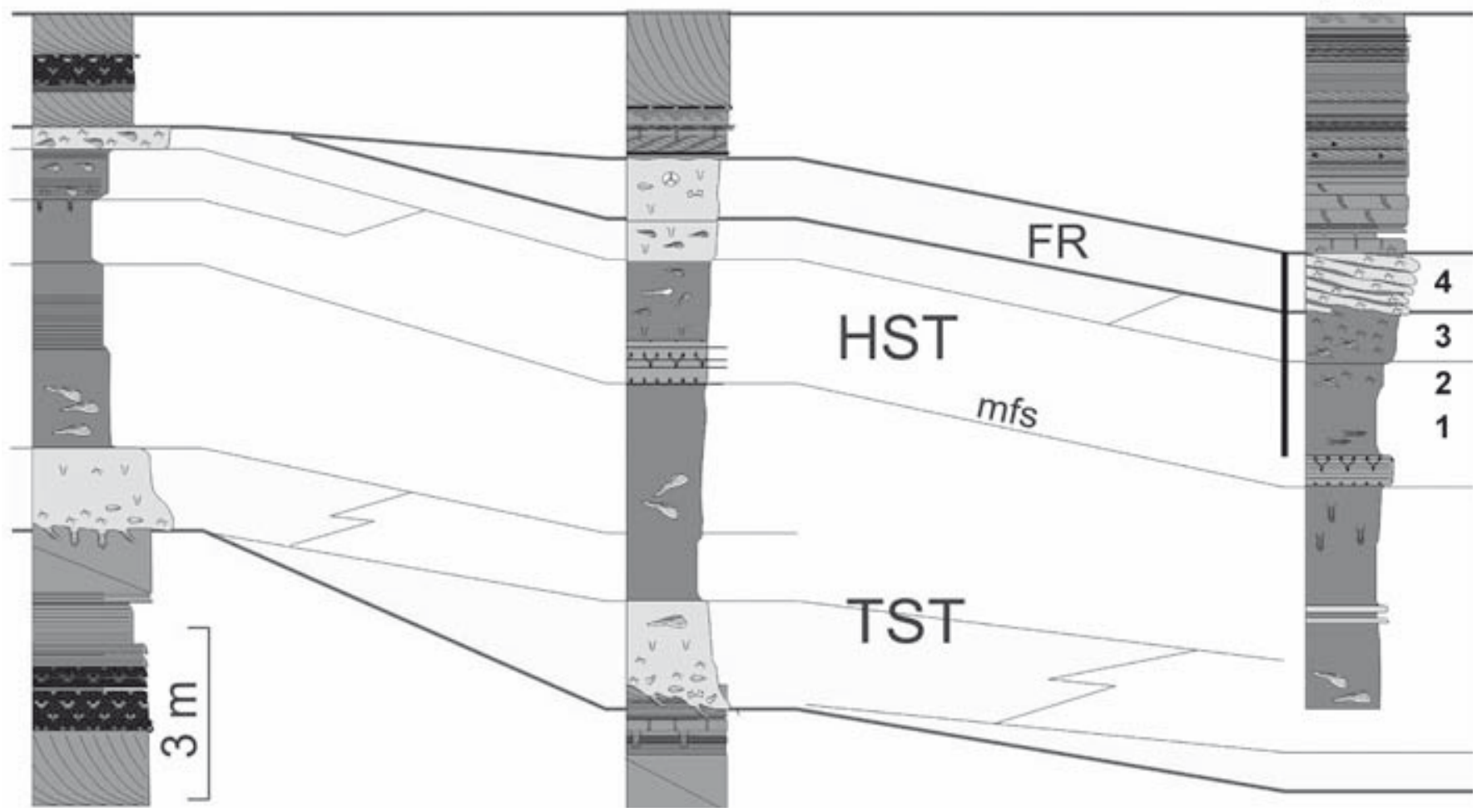

Figure 2. Stratigraphical correlation of the Río Negro Formation middle (marine) member among the main outcrops of the area. TST: transgressive systems tract; HST: highstand systems tract; FR: forced regression; mfs: maximum flooding surface. Vertical bar indicates the studied section in El Espigón outcrop and numbers correspond to the described layers (modified from Farinati \& Zavala, 2002). 


\section{MATERIAL AND METHODS}

Though the marine section of the Río Negro Fm is accessible at several locations on the NE coast of Patagonia, the present study has focused on the El Espigón site (Farinati \& Zavala, 2005) (Fig. 1). The three most complete sections of the cliff (La Lobería, Playa Bonita and El Espigón) were described by Zavala \& Freije (2000), and more recently enhanced by the description of bioturbation and microbially induced sedimentary structures (Carmona et al., 2012, 2013). Farinati \& Zavala (2005) carried out the study of their fossil invertebrate content. In this latter paper, the authors paid special attention to the Playa Bonita sequence, considered as the most complete outcrop, though they provided some complementary information from other sections. Currently, significant rockfalls occurring along the cliff make access to most of the Playa Bonita section impossible. As a result of this difficulty we decided to focus this research project on a detailed analysis of El Espigón, the easternmost outcrop, considered by Zavala $\&$ Freije (2000) as the outcrop which provides a record of the deepest sediments.

El Espigón site corresponds to a section of the cliff that allows the observation of Miocene strata along around $150 \mathrm{~m}$ of coast. The maximum outcropping thickness is 50 $\mathrm{m}$, of which the lowest $6 \mathrm{~m}$ corresponds to the upper part of the middle member of the Río Negro Fm (Figs 2, 3).

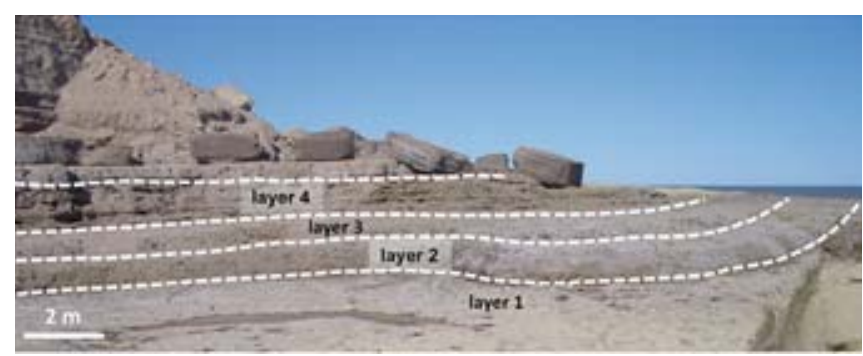

Figure 3. General overview of El Espigón outcrop, showing the four described main shelly layers.

The fieldwork consisted in measuring three stratigraphic sections in a W-E direction, with the three sections being spaced approximately $35 \mathrm{~m}$ apart (Fig. 4). On the basis of the lithological features, taxonomic characteristics and taphonomic attributes of fossils, four main layers observable in every section and along the outcrop were identified. A surface of $2 \mathrm{~m}^{2}(2 \times 1 \mathrm{~m})$ was randomly delimited on each section, and countings were carried out of: articulated $v s$. disarticulated valves, bored $v s$. unbored valves, encrusted $v s$. non-encrusted valves and the location of the encrusters on the internal or external side of the valves. Qualitative observations on fragmentation and degree of abrasion were also made.

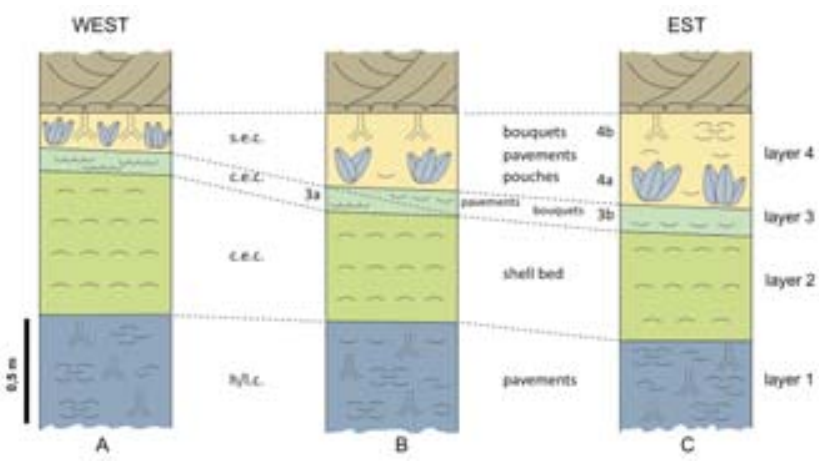

Figure 4. Schemas of the three sections at El Espigón outcrop (A, B and C), stressing the four levels described and the diferent kinds of oyster concentrations. h/l.c.: hiatal to lag concentration; c.e.c.: composite event concentration; s.e.c.: simple event concentration.

The numerous specimens of $C$. patagonica constituted the main malacological material used for the study, and shells were analyzed both in the field and the laboratory. The only exception to this dominance corresponds to layer 2 , where $P$. camachoi is the dominant species. As a result of this observation special attention has also been paid to this second species, both in the taphonomic description and the data analysis.

In this locality, the shell thickness of C. patagonica reaches nearly $3 \mathrm{~cm}$, and up to $180 \mathrm{~mm}$ of umbonopallial diameter (i.e., the distance between the umbo and the posterior ventral edge). In addition to the evidence provided by the oysters, the accompanying fauna (other bivalves, cirripeds, corals, etc.), evidence of bioerosion by endoskeletozoans (sensu Taylor \& Wilson, 2002), and the encrustation by episkeletozoans, and bioturbation were also considered.

Finally, several types of shell concentrations have been genetically and morphologically characterized through their taphonomic attributes and sedimentological data.

\section{PALAEOBIOLOGICAL DATA ON CRASSOSTREA PATAGONICA}

Crassostrea patagonica is a fossil oyster species that inhabited the NE Argentinian coast during the late Miocene. It is a large, heavy and thick-shelled oyster with left valves that may reach $30 \mathrm{~cm}$ in umbonopallial diameter, $20 \mathrm{~cm}$ of anteroposterior diameter and up to 5 $\mathrm{cm}$ of shell thickness. Right valves are somewhat smaller and nearly flat (Mauna et al., 2005).

Generally speaking, oysters are epibenthic bivalves that have the ability to adapt to varied environments and substrates. Recent oysters inhabit shallow waters, from 
the intertidal area down to $30 \mathrm{~m}$ depth. They develop better under slightly brackish water conditions in restricted marine environments, and between temperate and warm temperatures. Oysters can cement themselves to hard substrates to form banks, or alternatively occupy soft sedimentary bottoms as secondary soft-bottom dwellers (Seilacher, 1984). In the Argentinian Miocene strata, $C$. patagonica appears under two different modes of life related to soft bottoms: forming clusters (bunched or clustered forms) and reclined (recliner boulder-shaped or gryphaeate forms) (del Río et al., 2001; Mauna et al., 2005). Both habits represent a free lifestyle on sandy or muddy soft seafloor.

Crassostrea patagonica clusters are formed by several individuals arranged in almost vertical positions and cemented to each other. Del Río et al. (2001) found a minimum of 3 specimens for these clumps in the late Miocene Puerto Madryn Fm, while Mauna et al. (2005) mention clusters of up to 30 individuals in the same formation. Moreover, these authors describe beds formed by clustered forms that reach more than $5 \mathrm{~m}$ in thickness and occupy several hundred square meters. Reclined forms correspond to isolated specimens in which the left (more convex) valve rested on the seafloor. Oysters with both kind of forms inhabited soft sandy or muddy bottoms in the shoreface to offshore environments, although their shells/valves are not always in place, but transported and accumulated away from their living area (del Río et al., 2001; Mauna et al., 2005).

Because of its epibenthic habit in quite shallow waters and the dimensions of its shells, $C$. patagonica represents a very suitable substrate for endo- and episkelotobionts. Farinati \& Zavala (2002) describe the presence of Entobia isp., Maeandropolydora isp. and Gastrochaenolites torpedo Kelly and Bromley in several valves of C. patagonica from the Río Negro Fm. For the latter ichnospecies, Lithophaga patagonica (d'Orbigny) was suggested as the most probable producer. Domènech \& Farinati (2007) found the same ichnotaxa, and also Caulostrepsis isp. in specimens from the same places. Mauna et al. (2005) studied the presence of Lithophaga borings in extant (Ostrea puelchana d'Orbigny) and Miocene (C. patagonica -mentioned as $O$. patagonica- and Ostrea alvarezii d'Orbigny) oysters from the San Matías Gulf area ( $\mathrm{N}$ to the Valdés Peninsula). Right and left valves of C. patagonica appeared bored in $98 \%$ of cases, while only $35 \%$ (mainly left valves) appeared bored in $O$. puelchana and $O$. alvarezii. This difference can be explained because of their distinct life habits: $C$. patagonica lived according to their clustered habit, while the current $O$. puelchana lay down as a reclining form, like $O$. alvarezii did in the Miocene.

Farinati et al. (2010) attempted to explain why shells of $C$. patagonica collected at Playa Bonita outcrop attained such high values of size and thickness, with the maximum length and thickness being $15 \mathrm{~cm}$ and 4 $\mathrm{cm}$ respectively. These authors concluded that species longevity, high growth rate induced by the abundant availability of nutrients, pressure due to bioeroders, and a special shell microstructure contributed to their large sizes. In fact, $C$. patagonica populations in the area were under chronic stress as a result of bioerosion, a situation that modern oysters have overcome by becoming adapted to environments which are less favourable to potential bioeroders (estuaries, lagoons).

Finally, it is worth noting that this species was originally ascribed to the genus Ostrea by d'Orbigny, and later authors maintained this attribution. Griffin \& Nielsen (2008) reviewed the type material and included the species in the genus Crassostrea on the basis of shell morphology.

\section{SEDIMENTOLOGIC AND TAPHONOMIC DESCRIPTION OF THE LAYERS}

As indicated above, four main layers have been identified in the marine level of El Espigón outcrop, each with its own sedimentary and fossiliferous characteristics (Figs 3, 4).

\subsection{Layer 1}

This layer is composed of massive light grey mudstones, approximately $50 \mathrm{~cm}$ in thickness. It is characterized by the presence of $C$. patagonica accumulations and bioturbation (Fig. 4). However, the dominance of these elements is not uniform throughout the layer, and varies greatly along the outcrop.

Oysters are usually loosely packed, clearly matrixsupported, and they are accompanied by some small Chlamys spp. and cirripeds (Balanus laevis Bruguière). This latter encrusts the valves, sometimes in high numbers (between 70 and 100 individuals on a single shell), but they also appear in free groups. Equally remarkable is the presence of bioerosion affecting the oyster shells in this layer. Nearly $60 \%$ of shells show traces (Fig. 5), attributed to the activity of sponges (Entobia isp.), annelids (Caulostrepsis taeniola Clarke) and bivalves (large specimens of G. torpedo). Oysters are largely disarticulated $(90 \%)$ and valves appear concordant to the bedding planes, though sporadically some shells are complete and show a sub-vertical position.

Near the top of the layer there are some small (about $25-30 \mathrm{~cm}$ in maximum diameter), irregularly contoured clumps of oyster valves, with a chaotic shell distribution in their interior (Fig. 6a). Clumps are laterally replaced by shell pavements, some of which are slightly oblique to the bedding planes (about $5^{\circ} \mathrm{W}$ of dip), and all the individual shell pavements cut across each other (Fig. 6b). 

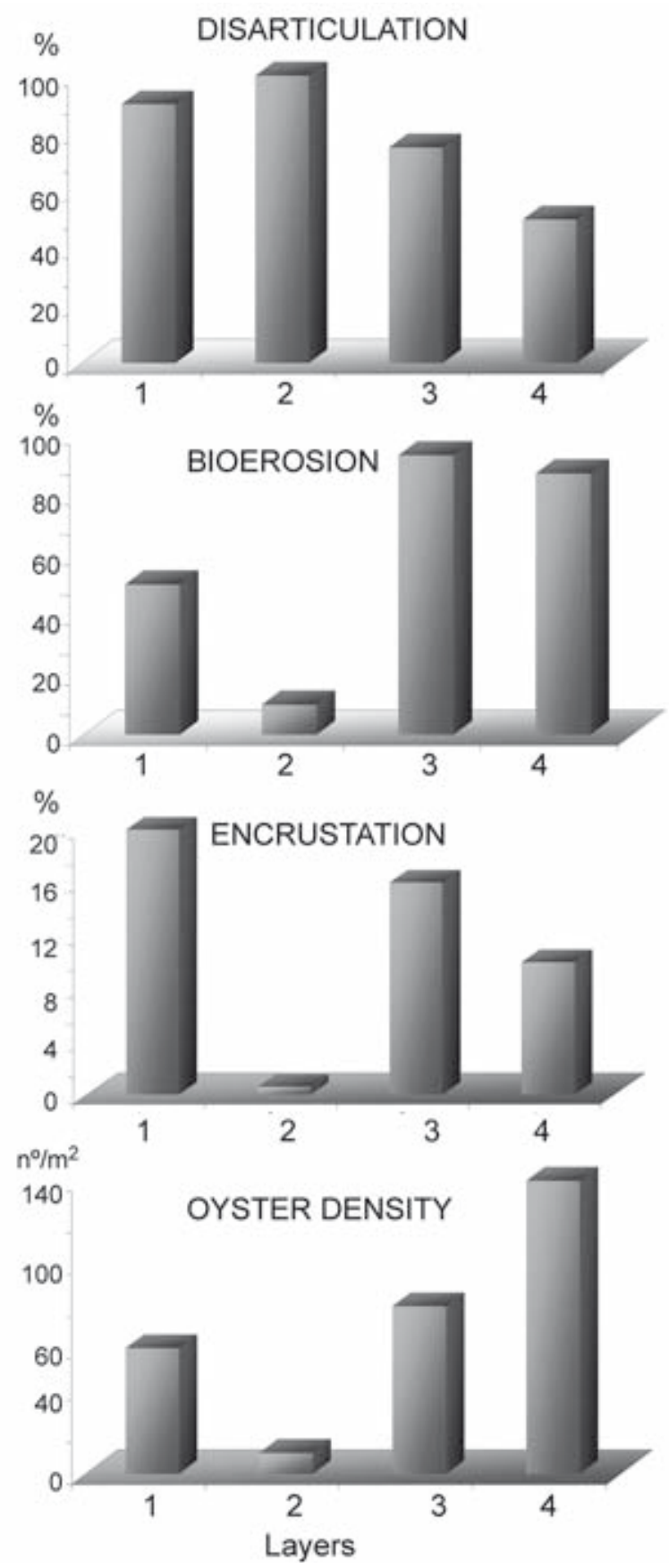

Figure 5. Histograms representing the main taphonomic attributes (percentage of disarticulated, bioeroded and encrusted oyster valves, and oyster density in a randomly chosen $1 \mathrm{~m}^{2}$ area) quantified in each of the four layers of El Espigón outcrop. See the text for more details.

The countings in a selected area, located at the top of the layer, yielded 60 valves of C. patagonica, disarticulated in $90 \%$ of cases (Fig. 5). The percentages of right/left valves are unavailable because of the difficulty in assigning them correctly. Bioerosion is present in $50 \%$ of the valves, with some of them highly affected by boring bivalves. Figure 6c, for example, corresponds to an impressive oyster "guest house" in this layer, with 22 perpendicular and oblique G. torpedo, which reach up to $30 \mathrm{~mm}$ in length. The proportion of encrusted valves is relatively low (20\%; Fig. 5). Nevertheless, encrusted shells are often completely covered by episkeletozoans (B. laevis), which occupy both the inner and the outer sides of the valves.

At the western end of the outcrop the layer maintains a $50 \mathrm{~cm}$ thickness. At its base, oysters mostly show a concordant disposition and are fragmented, but there is a similar number of left and right valves. Some shells are open but still hinged and with a concave-up attitude ("butterflied preservation") (Brett \& Baird, 1986; Schatz, 2004) (Fig. 6d). A small, discontinuous layer, formed by cirripeds (B. laevis) of considerable size (up to $2 \mathrm{~cm}$ in height) is present within the layer (Fig. 6e). Laterally, the base of the layer displays a network of Thalassinoides and Teichichnus among which oyster shells can be seen (Fig. 6f).

\subsection{Layer 2}

The second layer is composed of very fine-grained sandstones of about $50 \mathrm{~cm}$ in thickness (Fig. 4). Its main fossiliferous component is the bivalve Pododesmus camachoi del Río and Martínez, accompanied by randomly scattered oysters (Fig. 7a), Chlamys tehuelchus d'Orbigny, and Chlamys actinodes Sowerby. All the valves are loosely packed within the layer, in a clearly matrix supported arrangement. Moreover, some thin $(5-10 \mathrm{~cm})$, irregular levels with abundant skeletal remains appear at the top of the layer. They show a discontinuous distribution and are detected in the central and eastern parts of the outcrop.

The dominant taxon in the area selected for counting in this layer is the bivalve $P$. camachoi, which represents $87.6 \%$ of the recorded valves (120). The remainder are C. patagonica (10), and Ch. tehuelchus (7). Almost 100\% of the valves of $P$. camachoi are upper (left) valves, and appear loosely packed, concordant, and convex-upwards (Fig. 7b). Pectinids appear equally disarticulated and also display a concordant arrangement, but without a dominant orientation of the convexity, and with a similar number of left and right shells. Figure 5 reflects this high percentage of oyster disarticulation, reaching $100 \%$ of shells. Seven of the accounted Crassostrea valves show encrusted episkeletozoans (B. laevis), three contain G. torpedo and eight, Entobia isp. Bioerosion affects both inner and outer sides of the valves, although $G$. torpedo usually appears in the outer side, near the umbonal area, that is, in the thickest shell portion (Fig. 7a). Two specimens of the irregular echinoid Monophoraster darwini (Desor) have also been identified. 

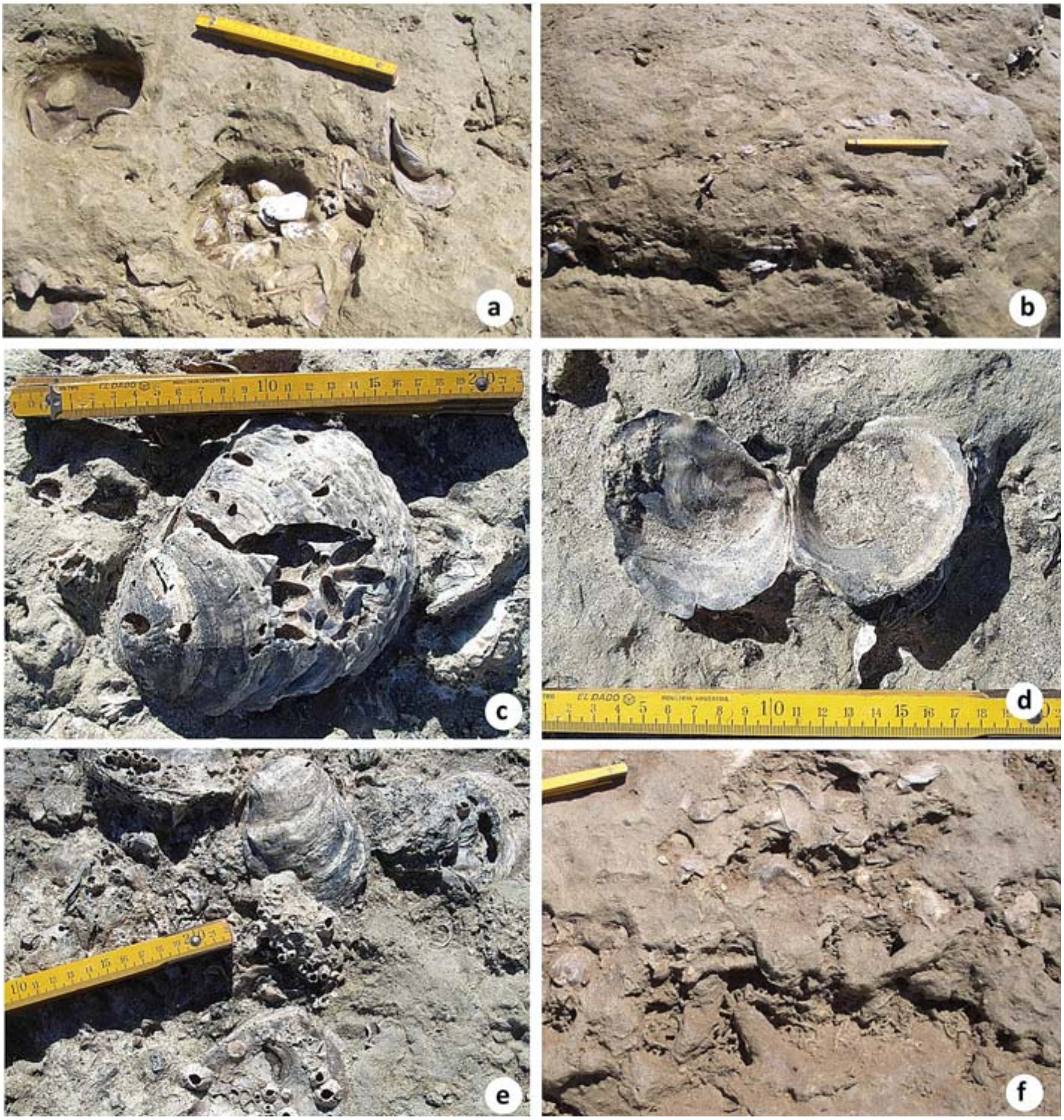

Figure 6. Layer 1. a) C. patagonica pouches with a chaotic inner fabric. b) Slightly oblique to the bedding planes pavements cutting each other because of erosion/deposition processes. c) C. patagonica with a high concentration of G. torpedo at the outer side of the valve. d) $C$. patagonica with convex-up butterflied preserved valves. e) Free valves of $C$. patagonica incrusted on both sides by B. laevis. f) Network of bioturbation traces (Thalassinoides isp. and Planolites isp.) with valves of $C$. patagonica trapped in it.

\subsection{Layer 3}

This layer is the most variable along the outcrop, as demonstrated by the sections (Fig. 4). Its easternmost part consists of about $10 \mathrm{~cm}$ of bioclastic sandstones with loosely packed, scattered oysters whose surface shows abundant bioerosion. The Western part of the outcrop, however, is formed by three base-asymptotic, cross stratified, overlying pavements with a slight $5^{\circ} \mathrm{E}$ dip. They are dominated by densely packed, heterometric, mostly 

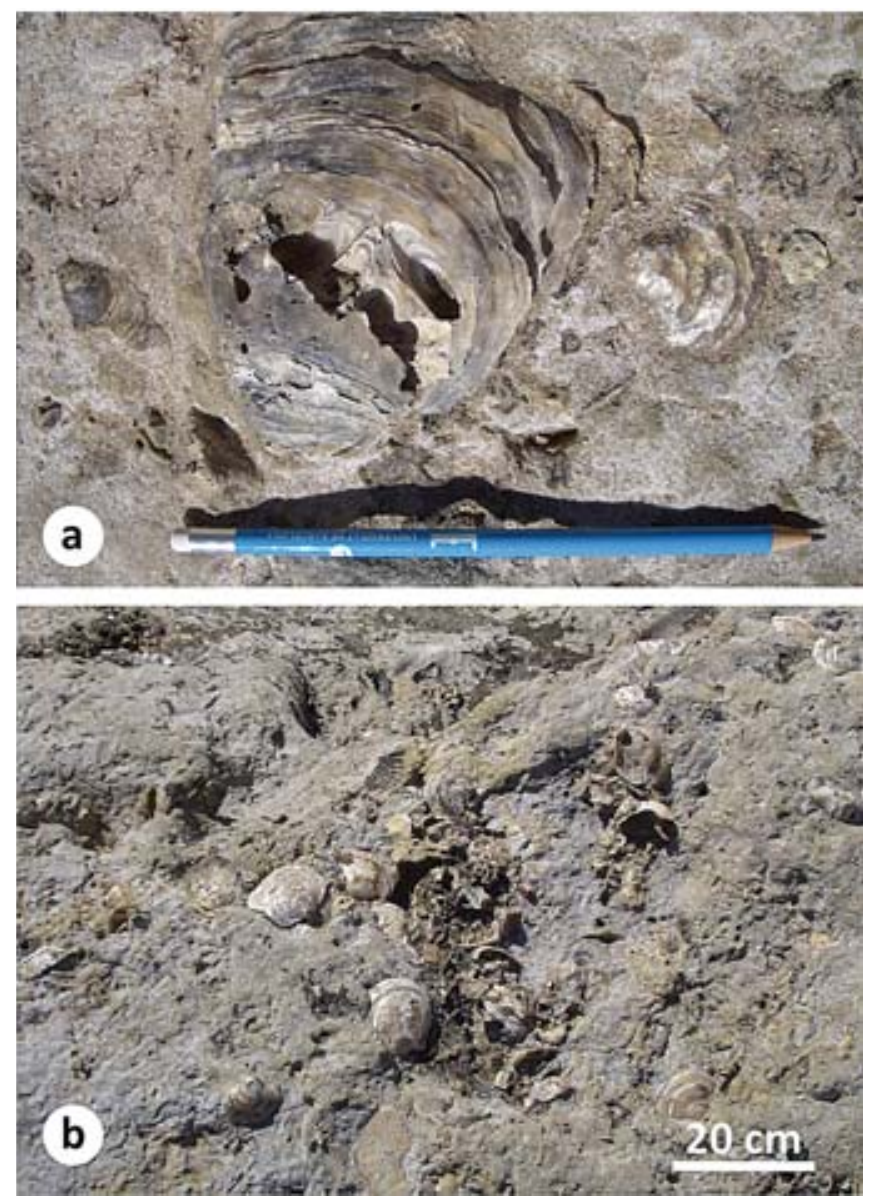

Figure 7. Layer 2. a) $P$. camachoi valves together with a $C$. patagonica valve with abundant lithophagous borings (G. torpedo). b) Distribution of P. camachoi valves showing their mainly convex up disposition.

disarticulated oysters, some completely bored and others pristine, accompanied by some pectinids and some cirripeds. Valves are distributed concordantly (Fig. 8a), convex or concave-up (Fig. 8b), or oblique. Some complete shells appear in subvertical positions (Fig. 8c) forming scarce bouquets. Dominant endoskeletozoan borings are Entobia isp. and G. torpedo (Fig. 8d). The matrix of these pavements is made up of heterometric shell fragments of a maximum size not exceeding $0.5 \mathrm{~cm}$. The central zone of the layer presents a more complex structure, which can be divided into sublayers $3 \mathrm{a}$ and $3 \mathrm{~b}$. The $3 \mathrm{a}$ sublayer forms the base and consists of an approximately $5 \mathrm{~cm}$ thick pavement which consists of disarticulated valves of $C$. patagonica, equivalent to the pavements observed in the western part of the outcrop. The overlying 3b sublayer (Fig. 9a) is composed of bioclastic sandstone with loosely packed, disarticulated valves of $C$. patagonica equivalent to the facies observed in the easternmost section of the layer (Fig. 9b).

The area selected for counting is situated in the $3 \mathrm{a}$ sublayer and corresponds to one of the oyster pavements (Fig. 5). Seventy specimens of C. patagonica were counted, 10 of which were complete shells and 60 were disarticulated valves. It was difficult to distinguish between right and left valves in the outcrop. The umbonopallial diameter of shells ranges from 3 to $15 \mathrm{~cm}$. Encrusting cirripeds (B. laevis) appear on $16 \%$ of the valves, and nearly $95 \%$ of the shells are bored on their outer side. All of them show Entobia traces (Fig. 8d) except eight which contain G. torpedo. Two valves display sponge borings on their inner surface. Borings occupy a large proportion of all the shell surfaces, and a small number of valves show both abundant $G$. torpedo and Entobia isp. The only $C$. patagonica shells which contain abundant Entobia isp. and G. torpedo on their outsides are those found in a subvertical life position (Fig. 8c).

\subsection{Layer 4}

Layer 4 is $50 \mathrm{~cm}$ thick on average and it also consists of two sublayers with variable characteristics (Figs 4, 10a). Overall, the layer tapers towards the western part of the outcrop. Where it is well developed, there is a lower layer (4a) consisting of a set of 5-6 cross stratified pavements, with an apparent inclination of about $5^{\circ} \mathrm{E}$, roughly parallel to each other both at the base and the top. These pavements consist of accumulations of loosely packed valves and some complete specimens of $C$. patagonica within a sandy bioclastic matrix, similar to, though thinner than those of layer 3. However, the upper pavement contains numerous complete specimens of $C$. patagonica in a subvertical position, forming clusters composed of several individuals of large size (between 15 and $18 \mathrm{~cm}$ in umbonopallial diameter) (Figs 10b-10c). These clusters are separated from each other, sharing the space with disarticulated valves (50\%; Fig. 11a). Oyster shells are dark coloured and show good preservation. Fragmentation is low, as well as abrasion, and there are no signs of valve dissolution. The fabric is matrix-supported and the clusters are embedded in bioclastic sediment where the maximum diameter of the skeletal fragments do not exceed $0.5 \mathrm{~cm}$ (Fig. 11b). The complete specimens maintain their valves fully articulated and the same external sediment infills the interior. Oysters in general show clear evidence of bioerosion (Entobia isp., C. taeniola and G. torpedo) (Figs $11 \mathrm{c}-11 \mathrm{~d}$ ), and some encrusting (serpulids, corals, cirripeds and bryozoans) (Figs 11e-11i). Bioerosion affects $99 \%$ of the valves. Sublayer $4 b$ is found above $4 a$. The boundary between these two sublayers is fairly sharp. Sublayer $4 \mathrm{~b}$ consists of one average $25 \mathrm{~cm}$ thick bioclastic sandstone. It exhibits intense bioturbation, represented primarily by Thalassinoides and Ophiomorpha (Fig. 10d). For more information, Carmona et al. (2013) provide further details on these traces. Bioturbation has a vertical development and it is sharply truncated at the top. This is, however, a general outline since the extent of these sublayers 

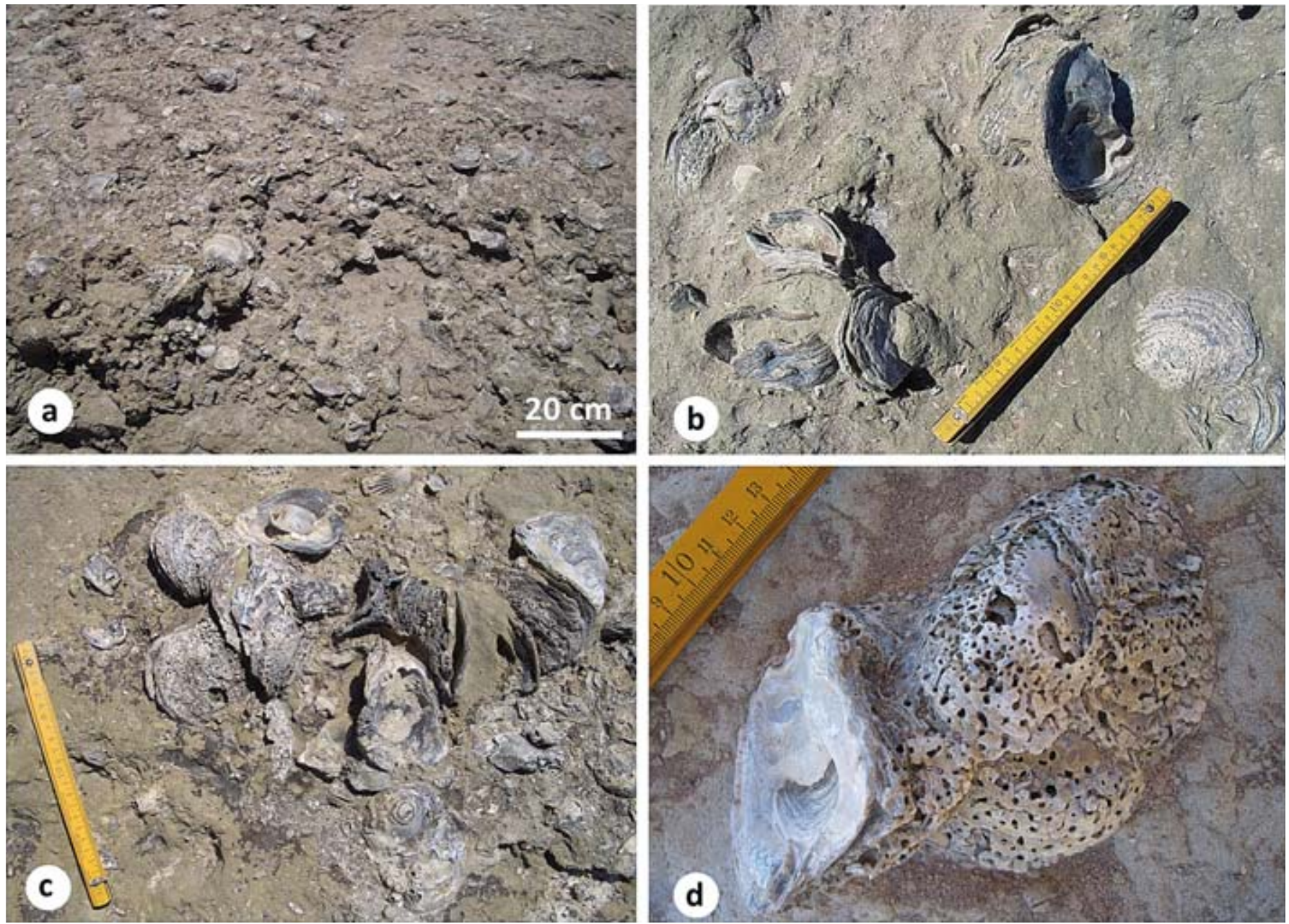

Figure 8. Layer 3a. a) Valves of $C$. patagonica concordant to the bedding plane. b) Some free valves of $C$. patagonica both upwards and downwards convexes. c) C. patagonica bouquet with abundant Entobia isp. and some G. torpedo. d) C. patagonica with abundant Entobia isp. and some G. torpedo.

displays a high degree of lateral variability within the outcrop. For example, there is a transition from areas with well-developed oyster clusters that occupy almost all the layer, with little to very abundant bioturbation with limited vertical development, to areas with no oysters and full occupancy by Thalassinoides, with intermediate situations between these extremes being displayed. The bioclastic underlying level, on which oysters are sustained, is constant throughout the outcrop. Towards the top, the bioclastic fraction varies in abundance and continuity, depending on the outcrop area considered. Sporadically, some small, badly defined pouches can be observed in it. However, the predominance of oyster clusters in almost the entire layer should be noted.

Disarticulation in this layer is relatively low (Fig. 5). On the surface demarcated for counting 140 valves appeared, consisting of 70 whole individuals ( 35 oysters with two valves) and 70 disarticulated valves, of which $14.2 \%$ are right valves. Disarticulated valves show a concordant, concave-up disposition. The umbonopallial diameter of these oysters ranges between 7 and $15 \mathrm{~cm}$. Among them, the incidence of encrustation is low, and only $10 \%$ of the valves present episkeletozoans (cirripeds and corals). Bivalve borings were not common, with only 4 specimens displaying G. torpedo. Instead, the boring activity of sponges is quite pronounced: $83 \%$ of the loose valves present Entobia isp. in their inner side, and $90 \%$ on their outer side.

\section{RESULTS AND \\ PALAEOENVIRONMENTAL INTERPRETATION}

\subsection{General taphonomic and ichnologic (bioerosion) observations}

The preservation of skeletal remains in the study area seems to be clearly influenced by the mineralogical composition 

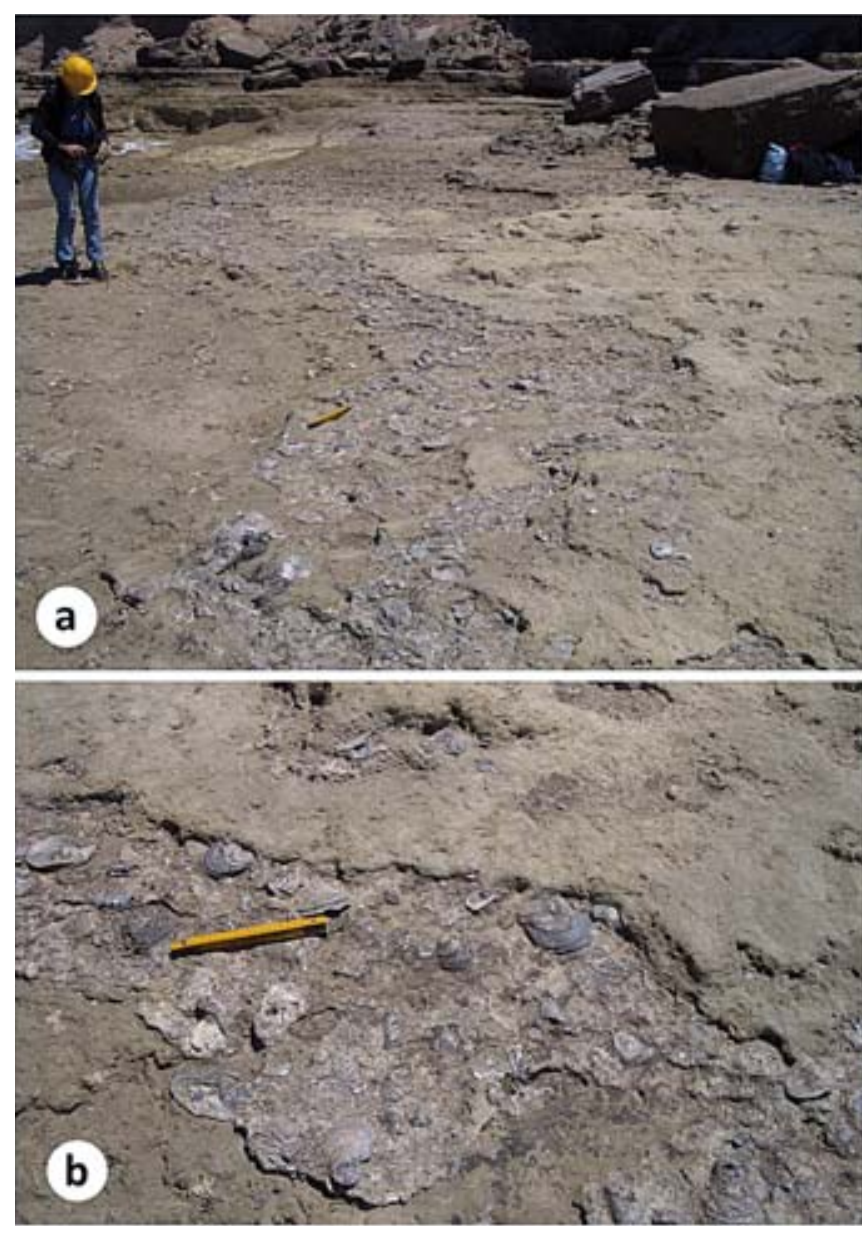

Figure 9. Layer $3 b$ (pavements). a) General overview of the layer. b) Detail of a pavement made by disarticulated C. patagonica valves.

and/or habitat of taxa. Although this aspect is not considered to be an important objective of this study, it is still worthy of comment. At El Espigón fossils belonging to endobenthic molluscs, which have mainly aragonitic shells, or to other endobenthic taxa, were not observed. However, in nearby outcrops (e.g., Playa Bonita), the presence of endobenthic bivalves preserved as molds in sedimentologically equivalent levels is common (Farinati \& Zavala, 2005).

Almost all the invertebrates identified at El Espigón had an epibenthic life habit and dominant calcite skeleton. The only exceptions to the primary skeletal composition are $P$. camachoi, an anomiid bivalve, and the scleractinian Oculina singleyi (Fig. 11h). In the first case, the original aragonitic skeletons are preserved in layer 2, whereas in the second, fossilization occurred as diagenetic calcite. The clypeasteroid echinoid Monophoraster darwini, whose skeletal mineralogy is calcite, was part of the more superficial endofauna. Therefore, it has to be stated that fossildiagenetic agents played an important role in the preservation of skeletal remains in this outcrop, perhaps from the very early stages. Thus, possible invertebrates with aragonitic skeletons living in this zone were not preserved. This would have facilitated the dominance of calcitic forms in the layers.

Moreover, the paucispecific composition of skeletal concentrations, dominated by $C$. patagonica, is to be stressed. Only the second layer is quite diversified, with the abundant presence of $P$. camachoi, several species of pectinids and some echinoids. In most cases, oysters appear in pouches or pavements, with clear evidence of biostratinomic processes, mainly transport evidenced by disarticulated and sorted valves and exposure prior to burial (borings and encrustation on the inner side of the valves).

Throughout the sequence, many of the valves of $C$. patagonica with Entobia are in fact intensely bored. It is especially notable in the clusters of layer 4 . Moreover, the valves with G. torpedo do not usually present Entobia or, in any case, this trace is in its early stages.

\subsection{Categorisation of the oyster shell concentrations}

Oyster concentrations represent a useful tool for palaeontologic and stratigraphic analyses because of their abundance and high fossilization potential. Domènech \& Farinati (2007) indicated the presence at El Espigón site of a biogenic oyster accumulation that corresponds to layer 4 described herein. The more detailed study of the outcrop allows for the categorisation of three different types of oyster dominated concentrations, which are characterized by the deposit geometry (Fig. 4) and their taphonomic attributes (Table 1):

\subsubsection{Type I: Pouches}

At the top of layer 1, some small C. patagonica pouches of irregular contour (about $25-30 \mathrm{~cm}$ in maximum diameter) appear with a chaotic distribution of valves within them (Figs 4, 6a). There is a smaller number of pouches, less defined than those in layer 1 , which are also sporadically present at the top of layer 4. The term "pouches" is here prefered instead of "clump" (proposed by Kidwell et al., 1986) to clearly differentiate them from the bouquets (type III, see below), also present in the sequence.

\subsubsection{Type II: Pavements}

There are pavements found particularly in layer 3, but also within layer 1 and at the base of 4, (Figs 4, 6b, $8 \mathrm{a}, 9 \mathrm{a}-9 \mathrm{~b})$ which are formed almost exclusively by $C$. patagonica. Valves have a high rate of disarticulation $(75 \%$ at layer 3) and they are arranged in a mostly concordant and convex-up manner. Density of specimens is locally high (40 valves $/ \mathrm{m}^{2}$ on the surface measured in layer 3 ). 
Table 1. Main taphonomical and sedimentological features of the concentrations studied.

\begin{tabular}{|c|c|c|c|c|c|c|c|c|}
\hline layer & $\begin{array}{c}\text { grain } \\
\text { size }\end{array}$ & $\begin{array}{c}\begin{array}{c}\text { concentration } \\
\text { types }\end{array} \\
\end{array}$ & disarticulation & bioerosion & incrustation & \begin{tabular}{|c|} 
relative \\
oyster density
\end{tabular} & \begin{tabular}{|c|} 
genetic \\
classification
\end{tabular} & environment \\
\hline 4 & & $\begin{array}{c}\text { I,II,III } \\
\text { (Crassostrea) }\end{array}$ & high / low & very high & low & high & simple event & shoreface/foreshore \\
\hline 3 & & II,III (Crassostrea) & very high & very high & medium & medium & composite & shoreface/foreshore \\
\hline 2 & & $\begin{array}{c}\text { IV } \\
\text { (Pododesmus) }\end{array}$ & very high & low & low & low & composite & shoreface \\
\hline 1 & & $\begin{array}{c}\text { I,II } \\
\text { (Crassostrea) }\end{array}$ & very high & medium & low & medium & hiatal to lag & shoreface \\
\hline
\end{tabular}

Likewise, pavements on layer 3 show the highest degree of bioerosion by endoskeletozoans ( $93 \%$ of the valves) and a relatively low encrustation rate (16.25\%; Fig. 5). Every pavement of layer 1 has a one-valve thickness and is matrix supported, while those at levels 3 and 4 are thicker, with 2-3 valves overlapping in many areas, although they are too thin to be considered true beds (sensu Kidwell et al., 1986).

\subsubsection{Type III: Bouquets}

This type corresponds to the oyster clusters of layer 4 (Figs $4,10 \mathrm{~b}, 11 \mathrm{e}-11 \mathrm{f})$. Its main characteristic is the presence of groups of several cemented individuals in a sub-vertical position, forming sets in life position, around which some disarticulated valves appear. Because this form of life, density of specimens is the highest in the outcrop (70 specimens $/ \mathrm{m}^{2}$ on the counting surface), and rate of disarticulation is the lowest $(50 \%)$. The life position of the bouquets clearly indicates the autochthonous character of the oysters and the absence of transport. Very scarce bouquets are also present in layer $3 \mathrm{a}$.

\subsection{Categorisation of the Pododesmus camachoi del Río \& Martínez Chiappara concentration (type IV)}

Layer 2 is dominated by P. camachoi, a sessile anomiid that had to live attached to a hard substrate through the byssus. This species was erected by del Río \& Martínez (1998) from specimens collected in La Lobería outcrop, a location which is very close to El Espigón site. Formerly, it has been identified as P. papyraceus Philippi (Farinati \&
Zavala, 2005). As stressed in the introduction, this species does not represent the main aim of the present research, but its local relevance within the section does merit special consideration. This is because the level contains a distinct, final category of shell concentration.

In the layer, valves of $P$. camachoi are $100 \%$ disarticulated, concordant, unfragmented, convex-up oriented, and loosely packed (matrix supported). They are left (upper) valves (100\% in the measured area), indicating a clear selection by light currents. The virtual absence of right valves in the layer and the orientation of the left ones suggest an effective sorting due to their different sizes, morphologies, and life position. Right valves (lighter, small and fragile, but fixed) may have remained attached to substrate and left valves (heavier, but convex and free) could have been transported to this locality, requiring a minimally continuous current action. The concordant and convex-up disposition of the valves indicates a reworking process and reorientation by flows in a regime of high friction with the sea-bottom (Kidwell, 1991a). Biostratinomic processes, therefore, are the primary control of the taphonomic signals in the layer and $P$. camachoi should be considered a parautochtonous component of the layer. Although rather dispersed, this skeletal association can be described as a shell bed (Fig. 4), which will constitute the fourth type of shell concentration in the outcrop.

\section{4. (Palaeo)environmental conditions of deposition}

Oyster pavements in layer 1 (type II) consist of single relict levels of mainly disarticulated and loosely packed valves, 

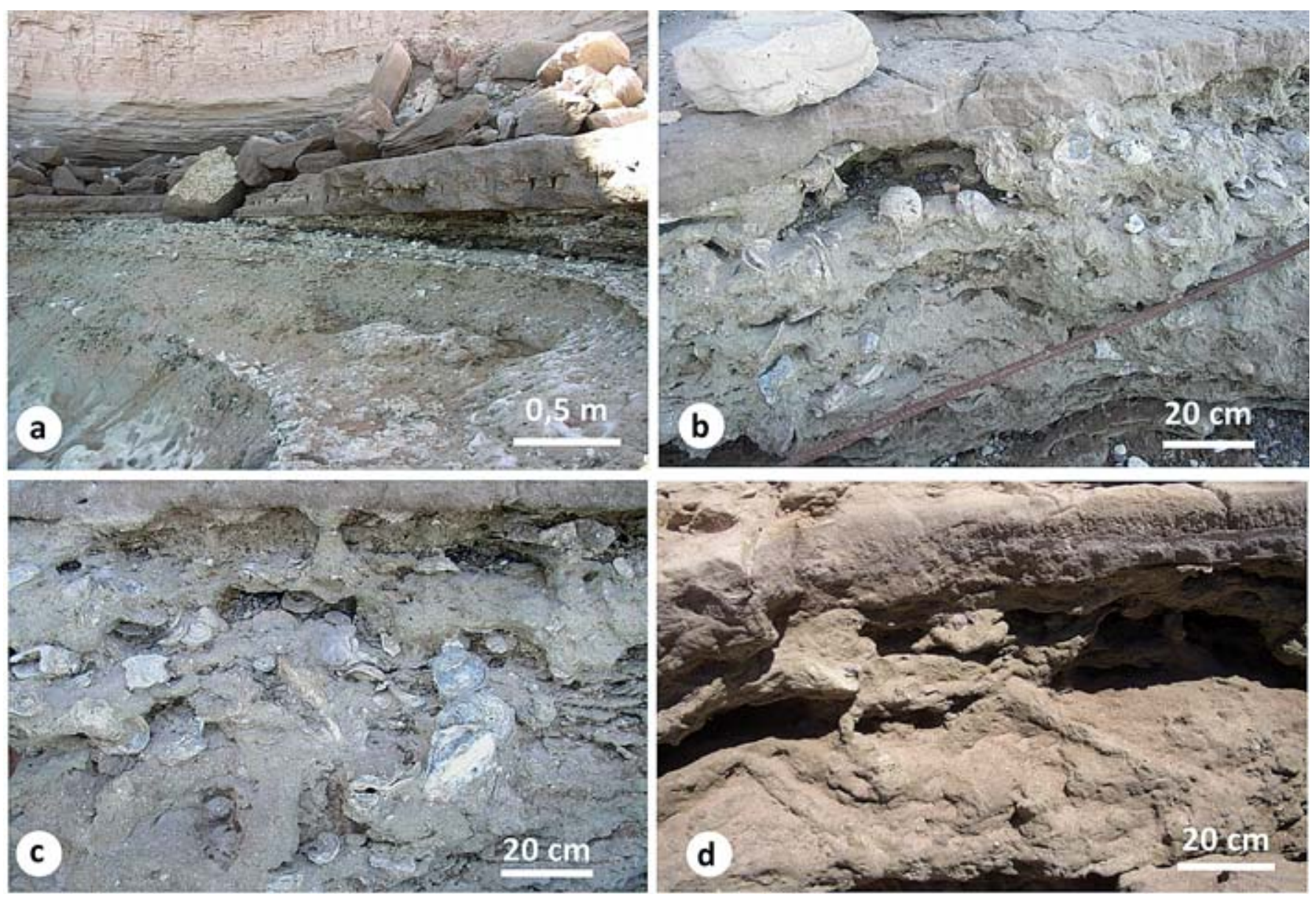

Figure 10. Layer 4 (I). a) General overview and erosive contact with the continental layers of the upper member. b) $C$. patagonica shells, many of them in life position forming bouquets. c) Detail of the oyster clusters at the base of the layer, together with some free valves in the matrix, which are replaced by Thalassinoides isp. towards the top. d) Detail of a Thalassinoides isp. network.

with a medium percentage of bioerosion or encrustation, although very intense in some particular specimens. Almost all the complete shells and free valves belong to oysters with a reclined habit. Pavements are usually the result of episodic transport in the foreshore/shoreface area (Kidwell et al., 1986). During these episodes there would be some erosion of the marine bottom and deposition of mostly concordant and convex-up valves. The coexistence of bored and pristine valves denotes mixing from different episodes, and also a low local rate of net sedimentation allowing timeaveraging. Different apparent dips of pavements in layer 1 (Fig. 6b) respond to alternating erosive and depositional episodes. Pavements change laterally to pouches (Fig. 6a) that could correspond to small depressions in the seafloor, where shells appear in a chaotic arrangement as a result of currents. A biogenic origin can be ruled out because of both the size and the thickness of the oyster valves. Sporadically, some oysters appear in a clustered habit, evidencing a life position; the loose valves could also correspond to this group, affected by transport.
In the Eastern part of the outcrop, it is also worth noting the presence of bioturbation (Thalassinoides and Teichichus) at the base of layer 1, showing oyster shells apparently concentrated in internal areas of the traces network (Fig. 6f). This arrangement can be interpreted as a result of the high activity carried out by endobenthic fauna during an episode of sedimentation decrease. Bioturbation affected previously buried shells and accumulated them within the Thalassinoides framework.

The loose pavements dominated by oysters in layer 1 could be tentatively referred as hiatal to lag concentrations, as they do not exactly correspond to either major surfaces of truncation, nor do they contain material from older deposits (Kidwell, 1991a). They must be associated with brief periods of erosion and short transportation.

The shell bed in layer 2, dominated by P. camachoi, shows a higher complexity and can be defined as a composite event concentration. The stratigraphic context indicates that these layers were deposited in shoreface/ foreshore environments at the begining of the HST (Farinati 

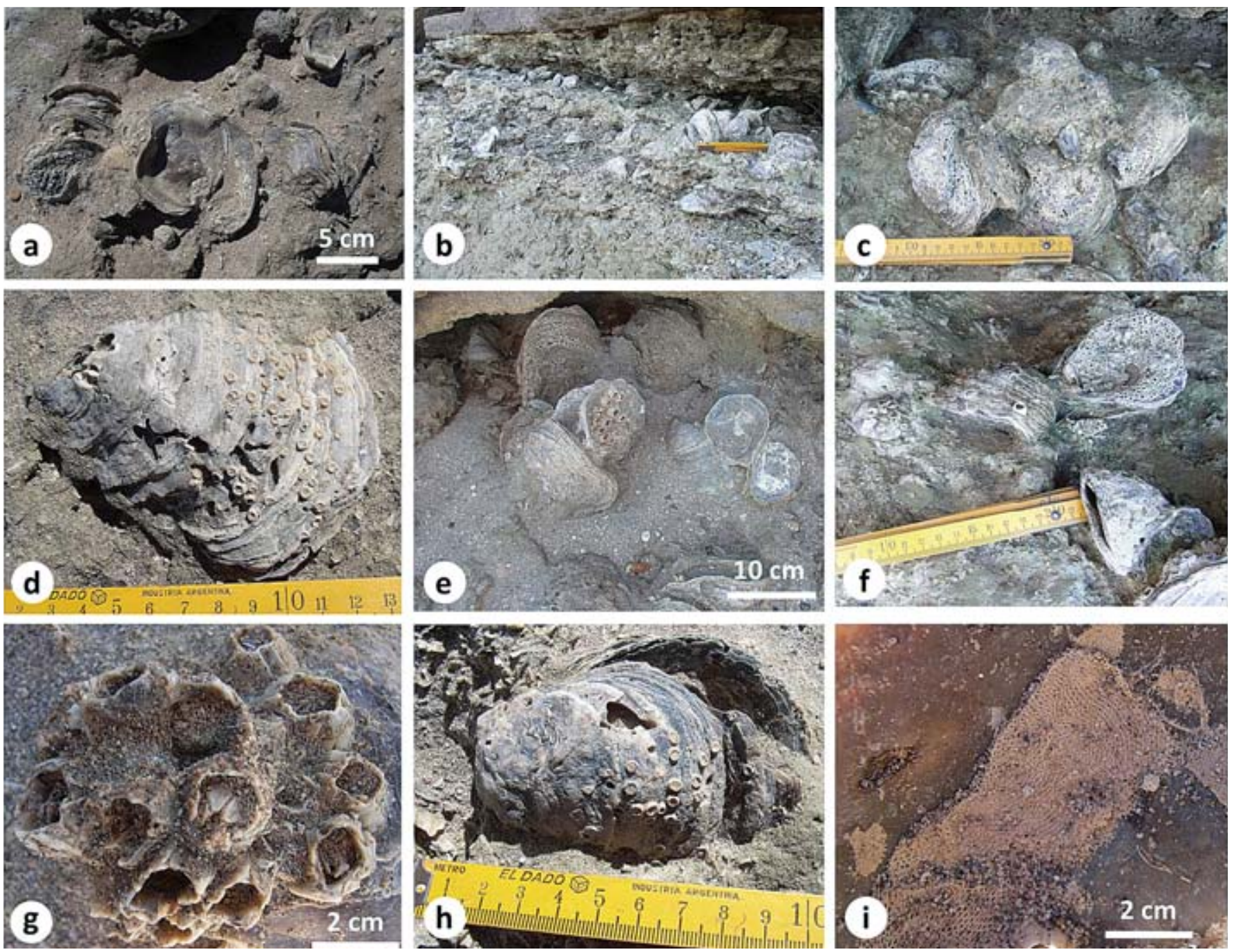

Figure 11. Layer 4 (II). a) C. patagonica in life position next to several disarticulated valves. b) General overview that demonstrates the way in which oysters grew from a bioclastic level formed by bioclasts. Bioturbation is visible at the top of the layer. c) C. patagonica bouquet with abundant Entobia in the valves. d) Oculina singleyi on C. patagonica with $G$. torpedo. e) Oysters bouquet next to some free valves; some specimens are pristine and others have attached Balanus laevis. f) Oysters bouquet with abundant encrustation by B. laevis. g) Detail of a B. laevis grouping encrusted on the outer side of an oyster shell. h) Oculina singleyi fixed on the outer side of a C. patagonica upper valve. i) Bryozoans colony and B. laevis encrusted on the inner side of a right $C$. patagonica valve.

\& Zavala, 2002; Carmona et al., 2013), which is consistent with the conditions inferred from taphonomic data.

The third layer is formed largely by oyster pavements (type II), but shows great lateral variability (Fig. 9b). This lack of uniformity is typical of coastal areas, with a clear wave and tidal activity. A low rate of sedimentation is interpreted due to the high rate of bioerosion and the relatively high rate of encrustation, as these processes need a relatively long residence time for the shells on the seaflor. These dipping oyster pavements represent foreshore frontal sheets and are more than the result of the addition of successive simple sedimentary episodes and thus, they may be qualified as composite event concentrations (Kidwell, 1991a).

Layer 4 is characterized by both oyster bouquets (type III) and bioturbation. The detrital bed, in turn, is almost in continuity with the pavements of the lower layer. The development of these oyster bouquets would be an example of taphonomic feedback (Kidwell \& Jablonski, 1983; Kidwell, 1991b), where bioclasts, derived largely from oyster shells, serve as a hard substrate for fixation. Bioerosion of the shells indicates stable conditions for a certain period of time, with a low rate of sedimentation. A single sedimentary event, however, buried the ensemble 
with almost all shells in life position (census assemblage, Kidwell \& Bosence, 1991). The result is a simple event biogenic concentration (Kidwell, 1991a) in the absence of time-averaging. Subsequently, the sediment that covered the oysters was affected by bioturbation, as reflected by the presence of Thalassinoides and Ophiomorpha networks. Layers 3 and 4 were deposited in a shallower environment than layers 1 and 2, and can be correlated with the upper shoreface/foreshore conditions established during the regression described in the depositional sequence (Zavala $\&$ Freije, 2000), as well as local sedimentation controlled by the algal mats that developed in protected areas of the palaeocoast (Carmona et al., 2012, 2013).

The upper boundary of the layer, however, abruptly cuts the traces, therefore demonstrating a significant erosional episode. This period may relate to subaerial exposure at the end of the regressive episode, with a $20-25 \mathrm{~cm}$ thick mudstone layer displaying desiccation structures.

\section{DISCUSSION}

The taphonomic features of the various shellbeds studied in the outcrop greatly support the classical stratigraphical interpretation (Zavala \& Freije, 2001) of the depositional sequence corresponding to the marine member of the Río Negro Fm. Nevertheless, these authors interpret the upper section as the result of a forced regression with an abrupt transition to the eolian member. The presence of oyster bouquets developed over a detrital bioclastic bed in this upper section may contradict an erosive episode. Carmona et al. (2012) describe a discontinuous level at the top of the HST, deposited under tidal flat conditions, where microbially induced sedimentary structures appear. These algal mats indicate that the transition to the subaerial conditions was not as sharp as previously considered, at least in some protected areas along the palaeocoast. This was probably the case for the sequence represented at El Espigón outcrop, which locally permited the development of small shelly buildings. The final preservation of the bouquets was made possible by a sudden irruption of sediment, subsequently affected by bioturbation.

Similar oyster bed sequences have been estudied in Phanerozoic sequences (Abbott, 1997; Fürsich \& Pandey, 1999; Pufahl \& James, 2006; Videt, 2007), and the Patagonian Cenozoic (del Río et al., 2001; Parras \& Casadío, 2005, 2006; Domènech \& Farinati, 2007; Farinati et al., 2010). Results presented in the current work are the equivalent of these previous studies in terms of of palaeoenvironmental and sequencial interpretations. Nevertheless, it is worth noting that the analysed sequence only represents the HST of the total transgressiveregressive cycle. The different concentration structures would only represent local or sporadic environmental conditions within a wide shoreface-foreshore domain. The uppermost concentration (level 4), related to the ending of the HST, would represent an atypical situation perhaps favoured by the presence of local algal-mats, or directly for their growth in a protected location that also promoted the development of microbial structures.

\section{CONCLUSIONS}

El Espigón outcrop allows for the examination of most of the marine middle member of the transgressiveregressive sequence of the Río Negro Formation (late Miocene-early Pliocene), North Patagonia. Four main layers have been identified, which contain different kinds of shell accumulations, mainly oysters. Bioturbation (Thalassinoides, Ophiomorpha, Teichichnus, Siphonichnus, Asterosoma, Maiakarichnus) and bioerosion traces (Entobia, Caulostrepsis, Maeandropolydora, Gastrochaenolites) are common in the outcrop, as well as encrusters (cirripeds, bryozoans and corals). These deposits were formed in shallow marine environments during the HST of the regressive sequence, affected by waves that gave rise to valve concentrations of different entities. C. patagonica is the almost exclusive species within these accumulations, which have been characterized by their geometry and their taphonomic attributes (Table 1). Thus, three different concentration morphologies have been identified for oysters: pouches, pavements and bouquets. In addition, a Pododesmus camachoi layer can be considered as a shell bed, having a taphonomic signature similar to that of the pavements. The most visible at the outcrop scale are the bouquet concentrations, but pavement concentrations are the most abundant. In layer 1, pouches and pavements are defined as hiatal to lag concentrations; in layer 3, every pavement is a simple event concentration, although the ensemble shows a more complex history (composite concentration), and in layer 4 , the bouquets correspond to a simple event biogenic concentration (census assemblage) without time averaging, and oysters are preserved mostly in life position. Concerning other fossil groups, P. camachoi shell bed in layer 2 could be also defined as a composite concentration.

Apart from oysters and anomiids, the main accompanying macrofauna is Chlamys tehuelchus, Ch. actinodes, Oculina singleyi, Balanus laevis and Monophoraster darwini. Layers 1 and 2 were deposited in shoreface/foreshore environments at the beginning of the HST, while layers 3 and 4 did were deposited at the end, or the very beginning of the regression, in clearer foreshore environments. The existence of algal mats in the top of the marine member indicates a not so abrupt change of environmental conditions and can explain the presence of oyster bouquets in life position in layer 4 . 


\section{ACKNOWLEDGEMENTS}

The comments and suggestions of J.M. de Gibert (Universitat de Barcelona) greatly improved the earlier versions of this text. Thank you, Jordi. The constructive critical contributions of the anonymous reviewers are also greatly appreciated. The revision of the English text has been done by Robert Hindson (Bristol, U.K.). This paper has been supported by the Universidad Nacional del Sur (Bahía Blanca, Argentina), Project 24/H077 S.C. y T., and the project CGL2010-15047 of the Spanish Government. It forms part of the activities of the Research Group on Palaeobiology of the Marine Neogene (Universitat de Barcelona).

\section{REFERENCES}

Abbott, S.T. 1997. Mid-cycle condensed shellbeds from mid-Pleistocene cyclothems, New Zealand: implications for mid-cycle sequence architecture. Sedimentology, 44, $805-824$.

Abbott, S.T. 2000. Detached mud prism origin of highstand systems tracts from mid-Pleistocene sequences, Wanganui Basin, New Zealand. Sedimentology, 47, 15-29.

Andreis, R.R. 1965. Petrografía y paleocorrientes de la Formación Río Negro (tramo General Conesa-boca del Río Negro). Revista del Museo de La Plata, Geología 36, 245-310.

Angulo, R.J. \& Casamiquela, R.M. 1982. Estudio estratigráfico de las unidades aflorantes en los acantilados de la costa norte del golfo de San Matías (Río Negro y Extremo austral de Buenos Aires) entre los meridianos 62 $30^{\prime}$ y $64^{\circ} 30^{\prime}$ W. Mundo Ameghiniano, 2, 20-73.

Aramayo, S.A. 1987. Plohophorus aff. figuratus (Edentata, Glyptodontidae) en la formación Río Negro (Mioceno tardío-Plioceno), provincia de Río Negro, Argentina. Importancia bioestratigráfica. X Congreso Geológico Argentino, Actas, 3, 171-174.

Aramayo, S.A. 2007. Neogene vertebrate paleoichnology of the North Atlantic coast of the Río Negro Province, Argentina. Arquivos do Museu Nacional, Rio de Janeiro, 65, 573-584.

Aramayo, S.A., Barros, M., Candel, S. \& Vecchi, L. 2004. Mammal and bird footprints at Río Negro Formation (Late Miocene-Early Pliocene), Río Negro Province, Argentina. First International Congress on Ichnology (ICHNIA 2004), Abstracts, p. 14.

Botquelen, A., Loi, A., Gourvennec, R., Leone, F. \& Dabard, M.-P. 2004. Formation et signification paléoenvironmentale des concentrations coquillières: exemples de l'Ordovicien de Sardaigne et du Dévonien du Massif armoricain. Comptes Rendus Palevol, 3, 353-360.

Brandt, D.S. 1989. Taphonomic grades as a classification for fossiliferous assemblages and implications for paleoecology. Palaios, 4, 303-309.
Brett, C.E. 1995. Sequence Stratigraphy, Biostratigraphy and Taphonomy in Shallow Marine Environments. Palaios, 10, 597-616.

Brett, C.E. \& Baird, G.C. 1986. Comparative taphonomy: A key to paleoenvironmental interpretation based on fossil preservation. Palaios, 1, 207-227.

Cantalamessaa, G., Celmaa, C.D. \& Ragaini, L. 2005. Sequence stratigraphy of the Punta Ballena Member of the Jama Formation (Early Pleistocene, Ecuador): insights from integrated sedimentologic, taphonomic and paleoecologic analysis of molluscan concentrations. Palaeogeography, Palaeoclimatology, Palaeoecology, 216, 1-25.

Carmona, N.B., Ponce, J.J., Wetzel, A., Bournod, C.N. \& Cuadrado, D.G. 2012. Microbially induced sedimentary structures in Neogene tidal flats from Argentina: paleoenvironmental, stratigraphic and taphonomic implications. Palaeogeography, Palaeoclimatology, Palaeoecology, 353-355, 1-9.

Carmona, N., Ponce, J.J., Wetzel, A., Bournod, C. \& Cuadrado, D. 2013. Marine trace fossils and microbially induced sedimentary structures of the Miocene-Pliocene Rio Negro Formation, Rio Negro Province, Argentina. SLIC2013-Second Latin American Symposium on Ichnology, Field-trips volume, 8-26.

Casamiquela, R.M. 1974. El bipedismo de los megaterioideos. Estudio de pisadas fósiles en la Formación Río Negro típica. Ameghiniana, 11, 249-284.

Damborenea, S.E. \& Lanés, S. 2007. Early Jurassic shell beds from marginal marine environments in Southern Mendoza, Argentina. Palaeogeography, Palaeoclimatology, Palaeoecology, 250, 68-88.

De Ferraris, C. 1966. Estudio estratigráfico de la Fm Río Negro de la Provincia de Buenos Aires. Anales de la Comisión Cientifica de la Provincia de Buenos Aires, 7, 85-165.

del Río, C.J. 1988. Bioestratigrafía y Cronoestratigrafía del Formación Puerto Madryn (Mioceno medio). Provincia del Chubut, Argentina. Anales de la Academia Nacional de Ciencias Exactas, Físicas y Naturales, 40, 231-254.

del Río, C.J. 1992. Middle Miocene Bivalves of the Puerto Madryn Formation, Valdes Peninsula, Chubut Province, Argentina (Nuculidae-Pectinidae). Part 1. Palaeontographica, 225, 1-57.

del Río, C.J. 1994. Middle Miocene Bivalves of the Puerto Madryn Formation, Valdes Peninsula, Chubut Province, Argentina (Lucinidae-Pholadidae). Part 2. Palaeontographica, 231, 93-132.

del Río, C.J. \& Martínez, S.A. 1998. El Mioceno marino en la Argentina y en el Uruguay. In: Moluscos marinos miocenos de la Argentina y del Uruguay (ed. del Río, C.J.). Monografía de la Academia Nacional de Ciencias Exactas, Físicas y Naturales, Buenos Aires, 15, 6-25.

del Río, C.J., Martínez, S.A. \& Scasso, R.A. 2001. Nature and origin of spectacular marine Miocene shell beds of Northeastern Patagonia (Argentina): Paleoecological and bathymetric significance. Palaios, 16, 3-25.

Domènech, R. \& Farinati, E.A. 2007. Análisis de concentraciones de ostras (Ostrea patagonica) en el 
Mioceno de Patagonia, Argentina. Cuadernos del Museo Geominero, 8, 117-122.

d'Orbigny, A. 1842. Voyage dans l'Amerique Meridionale, 3(3), París et Estrasbourg.

Farinati, E.A. \& Zavala, C. 2002. Trace fossils on shelly substrate. An example from the Miocene of Patagonia, Argentina. Acta Geologica Hispanica, 37, 29-36.

Farinati, E.A. \& Zavala, C. 2005. Asociaciones de megafósiles de invertebrados en el Neógeno atlántico de la Patagonia Argentina. Revista de la Sociedad Geológica de España, 18, 187-194.

Farinati, E.A., Aramayo, S.A. \& Terraza, J.C. 1981. La presencia de un nivel marino en la Formación Río Negro (Plioceno superior) Provincia de Río Negro, Argentina. Anales del Segundo Congreso Latinoamericano de Paleontología (Porto Alegre), p. 651-665.

Farinati, E.A., Fernández, A.L., Higuera-Ruiz, R., Ibisate, R. \& Elorza, J. 2010. Respuesta morfológica y microestructural condicionada por estrés en Crassostrea patagonica (D’Orbigny) de la Formación Rio Negro (Mio-Plioceno), Patagonia, Argentina. Revista de la Sociedad Geológica de España, 23, 9-22.

Feruglio, E. 1950. Descripción geológica de la Patagonia. Dirección General Yacimientos Petrolíferos Fiscales, 2, 1-349.

Frenguelli, J. 1950. Rasgos generales de la morfología y de la geología de la Provincia de Buenos Aires. Lemit, 2(33), 1-72.

Fürsich, F.T. \& Oschmann, W. 1993. Shell beds as tool in facies analysis: The Jurassic of Kachchh, Western India. Journal of the Geological Society London, 150, 169-185.

Fürsich, F.T. \& Pandey, D.K. 1999. Genesis and environmental significance of Upper Cretaceous shell concentrations from the Cauvery Basin, southern India. Palaeogeography, Palaeoclimatology, Palaeoecology, 145, 119-139.

Fürsich, F.T. \& Pandey, D.K. 2003. Sequence stratigraphic significance of sedimentary cycles and shell concentrations in the upper Jurassic-Lower Cretaceous of Kachchh, western India. Palaeogeography, Palaeoclimatology, Palaeoecology, 193, 285-309.

Griffin, M. \& Nielsen, S.N. 2008. A revision of the type specimens of Tertiary molluscs from Chile and Argentina described by d'Orbigny (1842), Sowerby (1846) and Hupé (1854). Journal of Systematic Palaeontology, 6, 251-316.

Holland, S.M. 2001. Sequence Stratigraphy and Fossils. In: Palaeobiology: A synthesis (eds Briggs, D.E.G. \& Crowther, P.R.). Blackwell Science, Oxford. 548-553.

Kietzmann, D.A. \& Palma, R.M. 2009. Tafofacies y biofacies de la Formación Vaca Muerta en el sector surmendocino de la cuenca Neuquina: implicancias paleoecológicas, sedimentológicas y estratigráficas. Ameghiniana, 46, 321-343.

Kidwell, S.M. 1986. Taphonomic feedback in Miocene assemblages: Testing the role of dead hardparts in benthic communities. Palaios, 1, 239-255.

Kidwell, S.M. 1991a. The stratigraphy of shell concentrations. In: Taphonomy: releasing the data locked in the fossil record (eds Allison, P.A. \& Briggs, D.E.G.). Topics in Geobiology, 9. Plenum Publishing, New York, 211-290.

Kidwell, S.M. 1991b. Taphonomic feedback (live/dead interactions) in the genesis of bioclastic beds: Key to reconstructing sedimentary dynamics. In: Cycles and Events in Stratigraphy (eds Einsele, G., Ricken, W. \& Seilacher, A.). Springer-Verlag, Berlin, 268-282.

Kidwell, S.M. 1991c. Condensed deposits in siliciclastic sequences: Expected and observed features. In: Cycles and Events in Stratigraphy (eds. Einsele, G., Ricken, W. \& Seilacher, A.). Springer-Verlag, Berlin, 682-695.

Kidwell, S.M. \& Bosence, D.W.J. 1991. Taphonomy and time-averaging of marine shelly faunas. In: Taphonomy: releasing the data locked in the fossil record (eds Allison, P.A. \& Briggs, D.E.G.). Topics in Geobiology, 9, Plenum Publishing, New York, 116-209.

Kidwell, S.M. \& Jablonski, D. 1983. Taphonomic feedback: ecological consequences of shell accumulation. In: Biotic Interactions in Recent and Fossil Benthic Communities (eds Tevesz, M. \& Mac Call, P.). Plenum Press, New York, 195-248.

Kidwell, S.M., Fürsich, F.T. \& Aigner, T. 1986. Conceptual framework for the analysis and classification of fossil concentrations. Palaios, 1, 228-238.

Kondo, Y., Abbott, S.T., Kitamura, A., Kamp, P.J.J., Naish, T.R., Kamataki, T. \& Saul, G.S. 1998. The relationship between shellbed type and sequence architecture: examples from Japan and New Zealand. Sedimentary Geology, 122, 109-127.

Mauna, C., Casadío, S., Parras, A. \& Pascual, M. 2005. Abundance and distribution of Lithophaga (Mytilidae) in extant and fossil oysters: Taphonomic and paleobiological implications. Ameghiniana, 42, 395-405.

Melchor, R.N., Genise, J.F., Umazano, A.M. \& Superina, M. 2012. Pink fairy armadillo meniscate burrows and ichnofabrics from Miocene and Holocene interdune deposits of Argentina: palaeoenvironmental and palaeoecological significance. Palaeogeography, Palaeoclimatology, Palaeoecology, 350, 149-170.

Parras, A. \& Casadío, S. 2005. Taphonomy and sequence stratigraphic significance of oyster-dominated concentrations from the San Julián formation, Oligocene of Patagonia, Argentina. Palaeogeography, Palaeoclimatology, Palaeoecology, 217, 47-66.

Parras, A. \& Casadío, S. 2006. The Oyster Crassostrea? hatcheri (Ortmann, 1897), a physical ecosystem engineer from the Upper Oligocene-Lower Miocene of Patagonia, Southern Argentina. Palaios, 21, 168-186.

Pufahl, P.K. \& James, N.P. 2006. Monospecific Pliocene oyster buildups, Murray Basin, South Australia: Brackish water end member of the reef spectrum. Palaeogeography, Palaeoclimatology, Palaeoecology, 233, 11-33.

Ragaini, L. \& Di Celma, C. 2009. Shell structure, taphonomy and mode of life of a Pleistocene ostreid from Ecuador. Bolletino della Società Paleontologica Italiana, 48, 79-87.

Roth, S. 1898. Apuntes sobre la geología y paleontología de los territorios de Rio Negro y Neuquen. Revista del Museo de La Plata, 9, 3-57. 
Scasso, R. A., MacArthur, J., Del Río, C., Martínez, S. \& Thirlwall, M.F. 2001. ${ }^{87} \mathrm{Sr} /{ }^{86} \mathrm{Sr}$ Late Miocene age of fossil molluscs in the "Entrerriense" of the Valdés Peninsula (Chubut, Argentina). Journal of South American Earth Sciences, 14, 319-329.

Schatz, W. 2004. Palaeoecology of the Triassic black shale bivalve Daonella - new insights into an old controversy. Palaeogeography, Palaeoclimatology, Palaeoecology, 216, 189-201.

Seilacher, A. 1984. Constructional morphology of bivalves: Evolutionary pathways in primary versus secondary softbottoms dwellers. Palaeontology, 27, 207-237.

Sharafi, M., Ashuri, M. \& Moussavi-Harami, R. 2012. Stratigraphic application of Thalassinoides ichnofabric in delineating sequence stratigraphic surfaces (MidCretaceous), Kopet-Dagh Basin, northeastern Iran. Palaeoworld, 21, 202-216.

Taylor, P.D. \& Wilson, M.A. 2002. A new terminology for marine organisms inhabiting hard substrates. Palaios, $17,522-525$.

Videt, B. 2007. Typologie des assemblages d'ostréidés (Bivalvia) et interprétations paléoenvironnementales. Comptes Rendus Palevol, 6, 47-58.

Wichmann, R. 1918. Estudios geológicos e hidrogeológicos en la región comprendida entre la boca del Río Negro, San
Antonio y Choele Choel. Dirección General del Minería, Geología e Hidrogeología, 13, 1-44.

Yamashita, S., Matsuoka, H. \& Naruse, H. 2011. Formation processes of shell concentrations in the Lower Cretaceous estuarine sediments of the Okurodani Formation, Tetori Group, Gifu Prefecture, central Japan. Palaeogeography, Palaeoclimatology, Palaeoecology, 308, 476-491.

Zavala, C. \& Freije, H. 2000. Estratigrafía secuencial del Terciario superior marino de Patagonia. Un equivalente de la "crisis del Messiniano"?. Geotemas, 2, 217-221.

Zavala, C. \& Freije, H. 2001. On the understanding of aeolian sequence stratigraphy: an example from Miocene-Pliocene deposits in Patagonia, Argentina. Rivista Italiana di Paleontologia e Stratigrafia, 107, 251-264.

Zavala, C., Abrameto, A., Azúa, G., Freije, H., Inchentronn, C. \& Ponce, J.J. 2000. Estratigrafía de los acantilados marinos de la zona de El Cóndor - Bahía Rosa (Formación Río Negro, Mioceno-Plioceno), Provincia de Río Negro. II Congreso Latinoamericano de Sedimentología, Resúmenes, p. 186-187.

Zinsmeister, W.J., Marshall, L.G., Drake, R.E. \& Curtis, G.H. 1981. First Radioisotope (Potassium-Argon) Age of Marine Neogene Rio Negro Beds in Northeastern Patagonia, Argentina. Science, 212, 440. 